\title{
KAJIAN KRITIS TERHADAP TEORI POSITIVISME HUKUM DALAM MENCARI KEADILAN SUBSTANTIF
}

\author{
Sudiyana; Suswoto \\ Fakultas Hukum Universitas Janabadra \\ Yogyakarta sudiyanash@gmail.com
}

\begin{abstract}
Abstrak
Hukum, pertama-tama tata hukum negara, tampak dalam teori Positivisme, khususnya Jhon Austin (1790-1859), dengan analitical legal positivism. Jhon Austin yang dikenal sebagai the founding father of legal positivism, bertolak dari kenyataan bahwa terdapat suatu kekuasaan yang memberikan perintah, dan ada pada umumnya orang mentaati perintah-perintah pemerintah. Pandangan positivisme hukum, tidak akan memberikan pelayanan kepada masyarakat, hukum lebih represif. Bagaimanakah kritik terhadap teori positivisme hukum dalam memenuhi keadilan substantif. Permasalahan akan dikaji secara yuridis filosofis dengan menekankan pada analisa terhadap teori-teori hukum dan peraturan perundang-udangan yang berkaitan dengan hukum positif. Kajian kritis positifisme hukum, pembentukan hukum didasarkan pada nilai-nilai yang abstrak, bukan nilai-nilai yang hidup dan berkembang dalam masyarakat, sehingga hukumnya lebih represif, dan bukan responsive. Hukum tidak fungsional dan tidak pragmatis, Ia hanya melindungi sekelompok warga masyarakat elit, sehingga equality before the law dan rule of law, tidak jalan. Memprioritaskan doktrin kepastian hukum dibandingkan dengan keadilan dan kemanfaatan. Putusan hakim menempatkan keadilan legal formal (Legal justice) prosedural dibandingkan keadilan substantive dan keadilan sosial (social justice).
\end{abstract}

Kata kunci: positivisme hukum, keadilan susbstantif, praktik hukum.

\section{A. Pendahuluan}

Sebuah negara yang menganut faham negara hukum ${ }^{1}$, sudah sewajarnya Indonesia berkewajiban untuk melaksanakan pembangunan di bidang hukum guna menuju tatanan masyarakat yang tertib, damai, adil dan sejahtera. Konteks

\footnotetext{
${ }^{1}$ Ciri Negara hukum: adanya pembagian kekuasaan, ajaran Trias politika. Faham: Negara hukum materil, Negara yang tidak hanya memberikan perlindungan hukum kepada masyarakat tetapi juga Negara yang memberikan kesejahteraan kepada masyarakat.
} 
pembangunan hukum ${ }^{2}$ tentunya harus dimaknai sebagai sebuah perwujudan dari suatu pemikiran yang mendalam tentang bagaimana hukum nasional itu dibentuk, dilaksanakan/dipergunakan untuk mengatur kehidupan masyarakat, dan kemudian untuk ditegakannya.

Dilihat dari aspek struktur pembentukan hukum, maka sangat jelas bahwa makna hukum akan dipersepsikan sebagai bentuk hukum yang tertulis yakni peraturan perundang-udangan. Hukum adalah peraturan perundang-undangan yang dibentuk oleh sebuah badan yang mempunyai kewenangan, dengan disertai sanksi guna mengatur kehidupan sosial masyarakat. Hukum yang mempunyai arti yuridis $^{3}$, adalah hukum yang ditentukan pemerintah suatu negara yakni undangundang. Hukum dalam arti yang sebenarnya (properly so called) adalah hukum yang berasal dari negara dan atau yang dikukuhkan oleh negara. Hukum-hukum lain tetap dapat disebut hukum, (improperly so called) tetapi bukan dalam arti yuridis yang sesungguhnya.

Hukum, pertama-tama tata hukum negara, tampak dalam teori Positivisme, khususnya Jhon Austin (1790-1859), dengan analitical legal positivism. Jhon Austin yang dikenal sebagai the founding father of legal positivism, bertolak dari kenyataan bahwa terdapat suatu kekuasaan yang memberikan perintah, dan ada pada umumnya orang mentaati perintah-perintah pemerintah.

Tidak penting mengapa orang mentaati perintah-perintah pemerintah tersebut. Ada yang karena merasa berwajib memperhatikan kepentingan umum, ada yang karena takut akan kekacauan, ada yang karena merasa terpaksa, sama saja. Kalau tidak mentaati akan dijatuhkan sanksi.

Menurut Austin; untuk disebut hukum diperlukan adanya unsur; seorang penguasa (Souvereighnity), ada suatu perintah (command), ada kewajiban untuk menaati (duty), ada sanksi bagi mereka yang tidak mentaati (sanction) ${ }^{4}$.

\footnotetext{
2 Pembangunan hukum nasional yang dilakukan secara terencana, terpadu, dan berkelanjutan dalam sistem hukum nasional yang menjamin pelindungan hak dan kewajiban segenap rakyat Indonesia berdasarkan Undang-Undang Dasar Negara Republik Indonesia Tahun 1945;

3 Theo Huijbers, Filsafat Hukum, Kanisius, Yogyakarta, 1991. Hal 40.

${ }^{4}$ Ibid., hal 41
} 
Positivisme hukum dikenal juga sebagai teori hukum yang menganggap bahwa pemisahan antara hukum dan moral, merupakan hal yang teramat penting. Positivisme membedakan apa yang membuat suatu norma menjadi eksis sebagai standart hukum yang valid dan apa yang membuat suatu norma menjadi eksis sebagai standart moral yang valid. Bagi kaum positivis ${ }^{5}$, norma-norma hukum yang "bengis" pun, dapat diterima sebagai hukum asalkan memenuhi kriteria formal yang ada tentang hukum.

Lebih lanjut, dalam teori positivisme hukum dari Hans Kelsen, memandang bahwa hukum adalah suatu perintah memaksa terhadap perilaku manusia (law is a coercive order of human behavior). Hukum adalah kaidah primer yang menetapkan sanksi-sanksi (it is the primary norm wcih stipulates the sanction). Dalam konsep hukum murni (reine rechlehre, the pure theory of law) kelsen memandang bahwa hukum harus dibersihkan dari anasir-anasir yang sifatnya non hukum, seperti kultur, politik, sosiologis, dan sebagainya.

Positivisme menurut Prof. Herbert Lionel Adolphus Hart (1907-1992), membedakan lima arti dari "positivisme" seperti yang disebut dalam ilmu hukum kontemporer," yaitu ${ }^{6}$ :

(1) anggapan bahwa undang-undang adalah perintah-perintah dari manusia (command of human being);

(2) anggapan bahwa tidak perlu ada hubungan antara hukum dengan moral atau hukum yang ada dan hukum yang seharusnya ada;

(3) anggapan bahwa analisa (studi tentang arti) dari konsepsi-konspesi hukum :

a. layak dilanjutkan, dan

b. harus dibedakan dari penelitian-penelitian histories mengenai sesbab sebab atau asal-usul undang-undang dari penelitian sosiologis mengenai hubungan hukum dengan gejala sosial lainnya, dan kritik atau

\footnotetext{
${ }^{5}$ Achmad Ali., Menguak Teori Hukum (Legal Theory) dan Teori Peradilan (Judicialprudence)., Kencana Prenada Group, Jakarta, 2009. hal 55

${ }^{6}$ W. Friedman., Teori dan Filsafat Hukum, Telaah Kritis atasTeori-teori Hukum (susunan I), diterjemahkan dari buku aslinya "Legal Theory" oleh Mohamad Arifin., Rajawali, Jakarta., 1990., hal 147.
} 
penghargaan hukum apakah dalam arti moral, tuntutan sosial, fungsifungsinya, atau sebaliknya;

(4) anggapan bahwa sistem hukum adalah suatu "sistem logis tertutup" dimana putusan-putusan hukum yang tepat dapat dihasilkan dengan cara yang logis dari peraturan-peraturan hukum yang telah ditentukan terlebih dahulu tanpa mengingat tuntutan sosial, kebijaksanaan, norma-norma moral,

(5) anggapan bahwa penilaian-penilaian moral tidak dapat diberikan atau dipertahankan. Misalnya, Pernyataan tentang fakta, dengan alasan yang rasional, petunjuk, atau bukti. (non-cognitivisme dalam etika).

Berdasarkan pemikiran-pemikiran para eksponen positivisme tersebut, pada hakekatnya; dilihat dari bentuknya, teori positivisme hukum memandang bahwa hukum adalah Undang-undang, dilihat dari isinya, hukum adalah perintah dari penguasa; maka terdapat otoritas penguasa yang membentuk undang-undang. Dalam teori ini, keadilan bukanlah unsur dalam hukum. Keadilan dipandang sebagai unsur regulative, bukan unsur konstitutif. Hukum yang tidak memenuhi rasa keadilan tetap disebut hukum, walaupun merupakan hukum yang buruk.

Sistem hukum Indonesia telah mendapat pengaruh dari teori positivisme hukum, suatu faham yang dipengaruhi legisme. Hal ini dapat dilihat dalam ketentuan Pasal 15 Algemen Bepalingen Van wetgeving (AB), yaitu bahwa: Terkecuali penyimpangan yang ditentukan orang Indonesia dan orang-orang yang dipersamakan dengan orang Indonesia, kebiasaan bukanlah hukum, kecuali undang-undang menyatakannya. Pengaruh teori positivisme, pada dasarnya telah berlangsung sejak Zaman Hindia Belanda ketika diundangkannya Kitab Undangundang Hukum Perdata (Burgelijk wet Boek atau code civil) dan Kitab Undangundang Hukum Dagang (Wet Boek Van Koophandle atau code de commerce) pada tanggal 30 April 1847 dalam Stb. 1847 No. 23 (pengkodifisian hukum) ${ }^{7}$.

Di Era Negara Proklamasi Kemerdekaan Republik Indonesia, dan dengan ditetapkannya UUD'45 sebagai Undang-Undang Dasar atau hukum dasar tertulis (constitusi) pada tanggal 18 Agustus 1945, warna positivisme hukum tetap melekat. Pasal I Aturan Peralihan UUD’45 (amandemen ke-4), yang menyatakan

\footnotetext{
${ }^{7}$ Soetandyo W., Dari Hukum Kolonial Ke Hukum Nasional, Raja Grafika, Jakarta, 1994, hal 40.
} 
bahwa segala peraturan perundang-undangan yang ada masih tetap berlaku selama belum diadakan yang baru menurut Undang-Undang Dasar ini.

Seluruh peraturan hukum produk Hindia Belanda masih tetap berlaku, hal ini bertujuan agar selama masa transisi, jangan sampai terjadi kekosongan hukum, namun akibat negatifnya, selain berlangsung masa transisi tanpa batas, maka juga secara tidak sadar melanggengkan paradigma Hukum Barat yang positivistis. Menurut Ahmad Ali ${ }^{8}$, seyogyanya ketika berlangsung amandemen UUD’45, dicantumkan pembatasan masa berlakunya Aturan Peralihan, misalnya paling lama 10 tahun sejak UUD'45 diamandemen terakhir.

Pada zaman Orde Baru, rakyat yang diwakili oleh MPR, DPR, DPRD Prov, DPRD Kabuaten kedudukaannya sebagai lembaga yang melegalisasi kewenangan pemerintah/eksekutif. Peran eksekutif dalam membuat berbagai peraturan perundang-undangan demikian kuatnya ${ }^{9}$. Dengan programnya paket deregulasi dan Prolegnas, sampai zaman reformasi sekarang ini dengan lahirnya Undang-undang No.12 tahun 2011 tentang Pembentukan Peraturan Perundangundangan, merupakan warna dari positivisme hukum.

Dalam konteks negara hukum formal, yang bertujuan melindungi segenap bangsa Indonesia dan Seluruh tumpah darah Indonesia ${ }^{10}$, pandangan positivisme adalah tepat untuk dilaksanakan dan diimplemantasikan dalam rangka pembentukan hukum nasional. Sebab, teori positivisme hukum ini sangat kuat dalam mempengaruhi; otorisasi politik, bidang-bidang kehidupan: seperti ekonomi, sosial-budaya, keamanan dan ketertiban. Seluruh aspek kehidupan berbangsa dan bernegara diatur dengan dan dalam bentuk hukumnya yang tertulis yakni peraturan perundang-undangan. Hal ini sepadan dengan, tujuan utama hukum yang dipergunakan untuk; ketentraman umum, untuk menjaga kedamaian

\footnotetext{
${ }^{8}$ Ahmad Ali., op cit hal 6.

${ }^{9}$ Firman Muntaqo. Meretas Jalan Bagi Pembangunan Tipe Hukum Prograsif Melalui Pemahaman Terhadap Peranan Mazhab Hukum Positivis dan Non Positivis dalam Kehidupan Berhukum Indonesia. Dalam Buku "Satjipto Rahardjo" berjudul Membedah Hukum Progresif Penerbit Kompas, Januari 2008. hal 152.

${ }^{10}$ Pembukaan UUD’45 Alinea ke- 4.
} 
dalam setiap peristiwa dan berapapun harga yang harus dibayarkan.”terpuaskan keinginan masyarakat akan keamanan umum adalah tujuan dari tatanan hukum ${ }^{11}$.

Teori positivisme hukum ini berdampak pada aspek penyelenggaraan kehidupan berbangsa dan bernegara, sebagai wujud negara hukum, bahwa seluruh aparatur penyelengara negara dari tingkat pusat sampai daerah, dari pejabat tinggi hingga pejabat terendah dan seluruh warga negaranya semua berpegang dan mendasarkan pada hukum (undang-undang). Mulai dari peraturan perundangan yang tertinggi sampai pada peraturan pelaksanaan yang terendah dan konkrit, hingga seperti juklak dan juknis, merupakan landasan yuridis.-normatif.

Hukum bersifat normatif, mengatur dan mewajibkan. Disebut normatif ${ }^{12}$, apabila pemerintah yang sah mengeluarkan suatu peraturan menurut perundang-undangan yang berlaku, peraturan tersebut ditanggapi sebagai norma yang berlaku secara yuridis, yakni peraturan itu terasa mewajibkan, sedemikian rupa sehingga seorang yang tidak menurut peraturan itu dapat dikritik kelakuannya, bahkan dapat dituntut hukuman terhadapnya. Timbulnya permasalahan hukum dalam kehidupan bermasyarakat, adalah akibat adanya suatu pelanggaran atas ketentuan peraturan perundang-undangan.

Bagi kaum legalist-positivis, prioritas utama dalam penyelesaian masalah hukum adalah adanya jaminan kepastian hukum. Kepastian hukum, keadilan dan kemanfaatan adalah sebuah doktrin. Doktrin kepastian hukum mengajarkan kepada setiap pelaksana dan penegak hukum untuk mendayagunakan hukum yang sama untuk kasus yang sama. Inilah doktrin kaum positivis, yang dikenali pula sebagai doktrin the supreme state of (national) law yang mengajarkan dan meyakini adanya status hukum yang mengatasi kekuasaan dan otoritas lain, semisal otoritas politik. Inilah doktrin yang berkonsekuensi pada ajaran lebih lanjut agar setiap ahli hukum, khususnya yang tengah bertugas sebagai hakim,

\footnotetext{
${ }^{11}$ Philippe Nonet dan Philip Selznick ., Hukum Responsif, Terjemahan dari Raisul Mutaqien., Nusa Media, Bandung, 2010. hal 37.

${ }^{12}$ Theo Huijbers., Filsafat Hukum. Penerbit Kanisius, 1991, hal 45.
} 
tidak menggunakan rujukan-rujukan normatif lain selain yang terbilang norma hukum guna menghukumi sesuatu perkara ${ }^{13}$.

Ketika penegak hukum; Hakim, Jaksa, Polisi, dan Advokat atau para porfesional yang bekerja di bidang hukum, akan menyelesaikan permasalahan hukum maka mereka akan mencari hukumnya dalam suatu Kitab Undang-undang atau peraturan perundang-undangan. Baik untuk merumuskan peristiwa hukumnya maupun untuk menemukan solusi hukumnya. Pandangan ini tentu tidak salah, sebab setiap permasalahan hukum melalui pendekatan kwalifikasi ${ }^{14}$ dan metode interpretasi tertentu terlebih dahulu akan ditentukan sebagai termasuk dalam peristiwa hukum apa, sehingga kemudian dapat ditentukan hukumnya. Kegiatan mengkwalifikasi dan menginterpretasi merupakan bagian dari tugas hakim dalam rangka proses peradilan.

Dalam konsep kuno, yang ternyata masih berlaku bagi hakim di abad 21 ini, hakim hanya sekedar "terompet undang-undang' yang bersumber dari kalimat yang pernah dikumandangkan oleh Baron de Charles de Secondat Montesquieu (1689-1755) empat abad yang lalu: the judge as la bouche de la looi, as the mouthpiece of the law" ${ }^{15}$. Hakim hanyalah menerapkan apa kata undang-undang, ia tidak berkewajiban untuk mencari dan menggali nilai-nilai yang hidup dan berkembang dalam masyarakat. Bahkan ada kalimat yang lebih ekstrem legalistik dari Montesqiuieu ${ }^{16}$ : "Tidak dituntut hakim yang berfikir".

Demi kepastian dan jaminan akan kepatuhan, hanya norma hukum yang telah diundangkan, yang disebut hukum nasional yang positif, itu sajalah yang boleh digunakan secara murni dan konsekuen untuk menghukumi sesuatu perkara. Tidaklah norma hukum ini boleh dicampuri berbagai pertimbangan yang merujuk ke sumber normatif lain, seperti: moral, rasa keadilan, ideologi politik.

\footnotetext{
${ }^{13}$ Soetandyo Wignjosoebroto., Sebuah risalah ringkas "Kriteria dan Pengertian Hakim Dalam Perspektif Filosofis, Sosiologis dan Yuridis" bahan diskusi yang diselenggarakan dalam rangka Seminar Nasional bertema "Problem Pengawasan Penegakan Hukum di Indonesia" diselenggarakan oleh Komisi Yudisial dan PBNU-LPBHNU di Jakarta 8 September 2006. hal 1.

${ }^{14}$ Mengkwalifiisir berarti menilai peristiwa yang telah dianggap benar-benar terjadi itu termasuk hubungan hukum apa atau yang mana, dengan kata lain menemukan hukumnya (Sudikno Mertokusumo: 92).

${ }^{15}$ Achmad Ali., opcit. hal 477.

${ }^{16}$ Achmad Ali., opcit. hal 478.
} 
Diyakini orang, bahwa dengan dipatuhinya doktrin seperti itu secara murni dan konsekuen maka hukum akan amat berdaya untuk mengefektifkan berlakunya kaidah-kaidahnya guna menata kehidupan dan menegakkan tertib di dalamnya ${ }^{17}$.

Pengadilan dan aparat hukum adalah menteri-menteri sang raja. Mereka dianggap (dan mereka menganggap) sebagai instrumen penguasa yang mudah diatur. Institusi-institusi hukum melayani negara; mereka merupakan bagian yang tak terpisahkan dari negara ${ }^{18}$. Paradigma legalist positivis, lebih-lebih hakim sebagai terompet undang-undang harus segera dihapus dari praktek berhukum di Indonesia.

Pandangan positivisme hukum, tidak akan memberikan pelayanan kepada masyarakat, hukum lebih represif ${ }^{19}$, dengan karakterisasi bahwa:

1. Institusi hukum secara langsung dapat diakses oleh kekuatan politik, hukum diidentifikasi sama dengan negara dan ditempatkan di bawah tujuan negara (raison d'etat).

2. Langgengnya sebuah otoritas merupakan urusan yang paling penting dalam administrasi hukum.

3. Lembaga-lembaga kontrol yang terspesialisasi, seperti polisi, menjadi pusatpusat kekuasaan yang independent; mereka terisolasi dari konteks sosial yang berfungsi memperlunak, serta mampu menolak otoritas politik.

4. Sebuah rezim hukum berganda (dual law) melembagakan keadilan berdasarkan kelas dengan cara mengkonsolidasikan dan melegitimasi polapola subordinasi sosial.

5. Hukum pidana merefleksian nilai-nilai yang dominan; moralisme hukum yang akan menang.

Berdasarkan uraian sebagaimana tersebut di atas, timbulah suatu permasalahan hukum, sebab pandangan positiviisme terlalu mengedepankan legal formal dan kepastian hukum, dengan mengesampingkan keadilan substantif dalam praktek penegakan hukum di Indonesia. Bagaimanakah kritik terhadap teori positivisme itu untuk memenuhi keadilan substantif.

\footnotetext{
17 Soetandyo Wingjosoebroto Op cit., hal 2.

18 Philippe Nonet dan Philip Selznick ., Op cit. hal 39.

19 Philippe Nonet dan Philip Selznick ., Op cit. hal 37.
} 
Tulisan ini merupakan kajian yuridis filosofis yang menekankan pada analisa terhadap teori-teori hukum dan peraturan perundang-udangan yang berkaitan dengan hukum positif. Sebagai bahan yang dipergunakan adalah bahanbahan hukum :

1. Bahan hukum primair, yaitu kepustakaan berupa literatur-literatur hukum bidang keonomi dan leteraur-literatur bidang ekonomi.

2. Bahwan hukum sekunder, berupa peraturan-perundang-undangan bidang perekonomian.

3. Bahan hukum terisier, berupa kamus-kamus hukum.

\section{B. Pembahasan}

\section{Teorisasai Hukum}

Sebelum membahas tentang teori hukum (legal theory), terlebih dahulu memahami istilah teori itu sendiri, agar tidak terjadi kesalah pemahaman makna atas kata yang akan menjadi padanannya. Dalam dunia ilmu pengetahuan, istilah teori tidak akan terlepas dari kegiatan; penyelidikan, penelitian, diskusi, dan berbagai macam kegiatan yang bertujuan untuk pengembangan ilmu pengetahuan.

Teori berasal dari bahasa latin "theoría" yang berarti perenungan, yang berasal dari bahasa Yunani "thea" yang secara hakiki menyiratkan sesuatu yang disebut realitas. Menurut Soetandyo Wingjosoebroto dalam Footnote no.30, Otje Salman S dan Antón F. Susanto ${ }^{20}$, Teori adalah suatu konstruksi di alam cita atau ide manusia, dibangun dengan maksud untuk menggambarkan secara reflektif fenomena yang dijumpai di alam pengalaman (ialah amalam yang tersimak bersaranakan indera manusia). Sehingga ta pelak lagi jika berbicara teori seseorang akan dihadapkan kepada dua macam realitas, yang pertama adalah realitas in abstracto yang ada di alam ide imajinatif, kedua adalah padanannya yang berupa realitas di alam in concreto yang berada dalam pengalaman indrawi.

\footnotetext{
${ }^{20}$ Otje Salman S dan Antón F. Susanto., Teori Hukum, Mengingat, Mengumpulkan dan Membuka Kembali., Refika Aditama, Bandung, 2004., hal 21
} 
Menurut kamus Concise Oxford Dictionary, Teori ${ }^{21}$ merupakan indikator dari makna seharí-hari ,anggapan yang menjelaskan tentang sesuatu, khususnya yang berdasarkan pada prinsip-prinsip indpenden statu fenomena dan lain-lain yang perlu dijelaskan. Dalam Kamus Shorter Oxford Dictionary, Teori sebagai disiplin akademik "statu skema atau sistem gagasan atau pernyataan yang dianggap sebagai penjelasan dari kelompok fakta atau fenomena. Teori adalah suatu pernyataan tentang sesuatu yang dianggap sebagai hukum, prinsip umum atau penyebab sesuatu yang diketahui atau diamati. Bagi semua ahli, teori ${ }^{22}$ adalah seperangkat gagasan yang berkembang disamping mencoba secara maksimal untuk memenuhi kriteria tertentu, meski mungkin saja hanya memberikan kontribusi parsial bagi keseluruhan teori yang lebih umum.

Teori Sangat berhubungan dengan ilmu. Ilmu merupakan kegiatan untuk memecahkan masalah yang dihadapi setiap manusia. Menurut Van Peursen ${ }^{23}$, pada tahap fungsional, manusia dalam menghadapi masalah, bukan hanya terbebas dari kepungan alam gaib sebagaimana pada tahap mistis dan mempunyai pengetahuan berdasarkan penelaahan-penelaahan terhadap obyek disekitar kehidupannaya sebagaimana pada tahap ontologis, namun lebih dari itu dia memfungsionalkan pengetahuannya bagi kepentingan dirinya.

Dalam usaha untuk memecahkan masalah tersebut maka ilmu tidak akan berpaling kepada perasaan melainkan kepada pikiran yang berdasarkan penalaran ${ }^{24}$. Ilmu mencoba mencari penjelasan mengenai permasalahan yang dihadapinya agar dia mengerti mengenai hakekat permasalahan itu dengan demikian maka ia dapat memecahkannya, dan karena masalah yang dihadapi adalah nyata maka ilmu mencari jawabannya pada dunia yang nyata pula ${ }^{25}$. Ilmu dimulai dengan fakta dan diakhiri dengan fakta, Einstein berkata ${ }^{26}$, apapun juga

\footnotetext{
${ }^{21}$ Ibid., hal 21.

${ }^{22}$ Ibid., hal 23.

23 C.A. Van Peursen., Strategi Kebudayaan, diterjemahkan oleh Dick Hartono., Kanisius, Yogyakarta., 1988.

24 Jujun S. Suriasumantri., Filsafat Ilmu Sebuah Pengantar Populer., Pustaka Sinar Harapan, Jakarta, 2009. hal 123

${ }^{25}$ Ibid, hal 123.

${ }^{26}$ Ibid, hal 123.
} 
teori yang menjembatani antara keduanya. Menurut Jujun S. Suriasumantri ${ }^{27}$, Teori adalah penjelasan mengenai gejala yang terdapat dalam dunia fisik tersebut. Teori merupakan abstraksi intelektual dimana pendekatan secara rasional digabungkan dengan pengalaman empiris. Artinya, teori ilmu merupakan suatu penjelalsan rasional yang berkesesuaian dengan obyek yang dijelaskannya.

Masalah yang merupakan obyek yang akan dijelaskan oleh teori, merupakan sebuah realitas yang ada dalam kehidupan manusia. Realitas dapat dimaknai sebagai sesuatu yang dapat ditangkap panca indra (sense), dapat juga sesuatu yang adalah dalam alam fikiran manusia berupa ide, gagasan, konsep yang abstrak (abstract), namun tetap rasional. Sebagai sebuah realitas yang kemudian akan disepadankan dengan teori, adalah masalah-masalah dalam kehidupan manusia, sehingga ada teori ekonomi, teori sosial politik, teori hukum.

Teori hukum ${ }^{28}$, (Jurisprudence, legal theory) dapat dipandangg sebagai kelanjutan atau pengganti "Allgemeine Rechtslehre" yang timbul pada abad 19 ketika minat pada Filsafat Hukum mengalami kelesuan karena dipandang terlalu abstrak dan spekulatif, dan dogmatika hukum dipandang terlalu konkret serta terikat pada ruang dan waktu. Allgemeine Rechtslehre ini mulai tergeser oleh istilah "Rechtstheorie" yang diartikan sebagai teori hukum positif yang mempelajari masalah-masalah umum pada semua sistem hukum. Masalah itu mencakup ${ }^{29}$ : sifat hukum, hubungan antara hukum dan negara, serta hukum dan masyarakat, perangkat pengertian pokok dan berbagai metode untuk mempereoleh pengetahuan hukum, hubungan timal balik antara hukum nasional dan hukum Internasional.

Sedangkan Satjipto Raharjo, memandang bahwa teori hukum dapat disebut sebagi kelanjutan dari usaha mempelajari hukum positif ${ }^{30}$, setidak-tidaknya dalam urutan yang demikian itulah kita merekonstruksikan kehadiran teori hukum itu secara jelas. Menurut Radbruch ${ }^{31}$, tugas teori hukum adalah membuat jelas nilai-

\footnotetext{
${ }^{27}$ Ibid, hal 123 .

${ }^{28}$ Bernard Arief Sidharta., Refleksi Tentang Struktur Ilmu Hukum, Penerbit Mandar Maju, Bandung, 2009. hal 120.

${ }^{29}$ Ibid. Hal 121.

${ }^{30}$ Satjipto Raharjo., Ilmu Hukum., Citra Aditya Bakti, Bandung, 1991. hal 253

${ }^{31}$ W. Friedman, Opcit. Hal 2.
} 
nilai hukum dan postulat-postulat hukum sampai hingga dasar-dasar filosofisnya yang paling dalam. Teori hukum akan mempermasalahkan hal-hal seperti ${ }^{32}$ : mengana hukum itu berlaku, apa dasar mengikatnya? Apa yang menjadi tujuan hukum? Bagaimana seharusnya hukum itu dipahami? Apa hubungannya dengan individu, dengan masyarakat? Apa yang seharusnya dilakukan oleh hukum? Apakah keadilan itu? Bagaimanakah hukum yang adil?

Menurut Meuwissen, sebagaimana yang disampaikan Hari Purwadi ${ }^{33}$, Teori Hukum berada pada tataran abstraksi yang lebih tinggi ketimbang ilmu hukum; ia mewujudkan peralihan ke filsafat hukum. Teori hukum merefleksi objek dan metode dari berbagai bentuk ilmu hukum, sehingga dapat dipandang juga sebagai suatu jenis filsafat ilmu dari ilmu hukum.

Teori hukum dan konsep hukum itu lahir bersama dan ditengah-tengah peradaban umat manusia, melalui metode ilmiah tertentu. Perlu untuk dipahami mengenai perjalanan sejarah lahirnya suatu teori dan konsep hukum ${ }^{34}$, karena semua teori dan konsep hukum adalah sesuatu yang didasarkan pada pandangan atau aliran filsafat tertentu yang merupakan "anak kandung" dari suatu peradaban tertentu.

Berdasarkan perjalanan sejarah, secara garis besar teori hukum dapat dikelompokan menjadi 3 (tiga) bagian ${ }^{35}$ :

1) Teori Hukum Klasik (pramodern) yang mencakup: aliran Hukum Alam (Natural Law), Peradilan Kadi (Kadi Court), Teori Hukum Islam (Islamic Jurisprudence), Teori Hukum Jepang (Japan legal theory), Teori Hukum Adat, Aliran idealisme transendental (Transendental idealisme), Aliran Utilitis (Utilitiarianism), Positivisme hukum (Legal positivism), Formalisme Hukum (Legal formalism), Aliran Ilmu Hukum Historis (Hitorical jurisprudence), Aliran Hukum Marxist (Marxist Jurisprudence).

\footnotetext{
${ }^{32}$ Satjipto Rahardjo, Opcit. Hal 254.

${ }^{33}$ Bernard Arief Sidharta, Op cit. Hal 123

${ }^{34}$ Ahcmad Ali., Opcit. Hal 3.

${ }^{35}$ Achmad Ali, Opcit, hal 10-11.
} 
2) Teori Hukum Modern, mencakup: American legal realism, scndinavia legal realism, the sosiological movent in jurisprudence, the anthropology movement in jurisprudence, dan The psychology movement in jurisprudence.

3) Teori Hukum Kontemporer (postmodern), mencakup Justice theori dari John Rawls, Critical legal Studies, Neo-evolusionary pf law, The disorder of law, Law and Economic theory, Law and development theory, Feminist legal theory dan Mazhab legal process.

Pada saat sekarang ini terdapat teori termuthakir, yaitu Konsep segitiga plurarisme hukum (tringular concept of legal plurarism) ${ }^{36}$, yang pada intinya bahwa eksistensi kultur hukum yang sifatnya sangat pluraristis, melahirkan kebutuhan adanya sebuah teori hukum yang mampu menjelaskan fenomena plurarisme hukum, yang merupakan suatu realita, suatuteori yang diperkenalkan sejak tahun 2006 oleh Werner Menski, Profesor Hukum University of London. Dalam tulisan ini akan dibahas salah satu teori yang sangat mempengaruhi kehidupan berhukum di Indonesia, yaitu Teori Positivisme.

\section{Teori Positivisme Hukum}

Mulai abad XIX, alam pikiran manusia memasuki pada tahapan dalam kehidupan zaman modern, dan meninggalkan tahapan kehidupan yang metafisis, sebagai tahapan dimana orang mencari kebenaran melalalui filsafat. Pada zaman modern tersebut, manusia mencari kebenaran melalui pendekatan ilmu pengetahuan ilmiah (Saintisme ${ }^{37}$ ).

Aliran empirisme38 yang berkembang pada abad sebelumnya tetap mewarnai kehidupan manusia di zaman modern, namun dalam bentuk yang berbeda yang disebut dengan positivisme.

\footnotetext{
${ }^{36}$ Achmad Ali, Opcit, hal 11.

${ }^{37}$ Saintisme adalah suatu paham (isme) falsafati yang meyakini kebenaran pernyataan bahwa pengetahuan manusia yang benar itu hanya dapat diperoleh melalui suatu metode - satu-satunya metode! - yang disebut metode sains. Lihat Soetandyo Wingjosoebroto. "Logika Filsafat Positivisme Dalam Pembangunan Epistemologi Hukum” dalam rangka „Kongres Ilmu Hukum' diselenggarakan di Universitas Diponegoro 9-20 Oktober 2012.

${ }^{38}$ Menekankan basis empiris bagi semua pemikiran manusia. Emipirisme yang berkembang di Inggris merupakan suatu berfikir yang rasional. Dalam metode empiris diutamakan: apa yang tidak dapat dialami, tidak dapat diakui kebenarannya. Tokohnya John Locke (1632-1704) dan David Hume (1711-1776). Theo Huijbers., Op cit. Hal 31.
} 
Positivisme kemudian berkembang dan mempengaruhi bidang kehidupan ekonomi, sosial politik, dan termasuk hukum. Dalam bidang hukum, secara epistemologis, teori positivisme hukum lahir sebagai kritik terhadap mazhab Hukum Alam (natural of law) yang menitik beratkan pada hubungan moral dan hukum, yang mengaitkan teorinya dengan dimensi mosaik (ke) manusia (-an). Bagi Positivisme yuridis ${ }^{39}$, hukum hanya ditangkap sebagai aturan yuridis, lebih khusus bentuk yuridisnya. Mengenai isi atau materi hukum bukan soal yang penting, ia menjadi bidang kajian ilmu lain, bukan wilayah kajian hukum. Ilmu hukum hanya berurusan dengan fakta bahwa ada tata hukum yang dibuat negara, dan karenanya harus dipatuhi, jika tidak maka sanksi akan diterapkan.

Hukum bukan persoalan adil atau tidak adil, dan juga bukan soal relevan atau tidak dengan pergumulan riil, satu-satunya yang relevan jika berbicara hukum, adalah ia ada dan sah secara yuridis ${ }^{40}$. Apakah sesuatu itu hukum atau bukan hukum, sama sekali tidak ditentukan oleh apakah sesuatu itu adil atau tidak adil, Positivisme mungkin merima adanya hukum tidak adil.

Dalam rangka kepentingan memberikan jaminan kepastian hukum, Positivisme Hukum mengistirahatkan filsafat dari kerja spekulasinya dan mengindetifikasi hukum dengan peraturan perundang-undangan, kepastian hukum akan diperoleh karena orang tahu dengan pasti apa yang boleh dan tidak boleh dilakukannya $^{41}$. Epistemologi Positivisme Hukum yang semula kritis terhadap hukum kodrat, menyudahi kekritisannya ketika menganggap Positivisme Hukum merupakan aliran paling akhir dan mutlak dari ilmu hukum.

Kaum Positivisme Hukum menganggap "kebenaran” ilmu praktek hukum telah final pada titik garis positivisme Hukum, sehingga merasa tidak akan ada perkembangan baru di waktu mendatang. Sebuah monumen yang menjadi tanda usainya dialektika dalam ilmu dan praktek hukum adalah kodifikasi ${ }^{42}$. Paradigma

\footnotetext{
${ }^{39}$ Bernard L. Tanya, dkk., Teori Hukum, Strategi Tertib Manusia Lintas Ruang dan Generasi., Gentha Publishing, 2013. hal 108.

${ }^{40}$ Ibid, hal 108.

${ }^{41}$ Widodo Dwi Putro., Kritik Terhadap Paradigma Positivisme Hukum, Genta Publishing, 2011. hal 25.

${ }^{42}$ Ibid, hal 25.
} 
Positivisme Hukum tumbuh pada abad ke-18 sebelum kapitalisme dominan ${ }^{43}$. Meskipun kapitalisme dan positivisme hukum merupakan 2 (dua) fenomena yang proses historisnya berbeda dan masing-masing berdiri sendiri-sendiri, dalam perkembangan kemudian, paradigma positivisme mempunyai pertalian erat dengan kapitalisme.

Paradigma positivisme mulai mempengaruhi hukum memodifikasi dirinya menjadi hukum modern sejak abad ke -19, suatu masa di mana kapitalisme mendominasi relasi mode of pruduction dan membutuhkan suatu hukum modern yang dapat memberikan jaminan kepastian hukum bagi perkembangan (akumulasi, eksploitasi, dan ekspansi) modal. Positivisme hukum dalam perkembangannya mempengaruhi negara-negara untuk menganut sistem kodifikasi, yang memandang UU merupakan satu-satunya sumber hukum yang pasti $^{44}$. Dalam sistem hukum Indonesia, hal ini ditegaskan pula dalam Pasal 3 Algemene Bepalingen Van Wegeving, yang menyatakan bahwa hukum dan undang-undang adalah identik, yang dipentingkan adalah kepastian hukum.

Dalam teori hukum positivisme, terdapat dua sub teori yang sangat terkenal, yaitu:

1) Teori Hukum Positif yang analaitis (analitical jurisprudence) dari John Austin;

2) Teori Hukum Murni (the pure of law theory) dari Hans Kelsen.

Teori hukum positif yang analitis mengartikan hukum itu sebagai perintah dari pembentuk undang-undang atau penguasa (a command of the lawgiver), yaitu suatu perintah dari mereka yang memegang kekuasaan tertinggi atau yang memegang kedaulatan.

Teori hukum positivisme (annaliyical positivisme) atau (rechtsdogmatiek) merupakan faham/aliran yang dominan di abad ke sembilan belas, hal ini disebabkan oleh dunia profesi yang membutuhkan dukungan dari pikiran positivisme-analitis yang membantu untuk mengolah bahan hukum guna

\footnotetext{
${ }^{43}$ Pandangan De Santos, sebagaimana dikutip oleh Widodo Dwi Putra, ibid hal 25.

${ }^{44}$ Mendasarkan pada faham Legisme dan Paraturan-Peraturan Umum (Algemene Bepalingen Van Wet Geving). Sudikno Mertokusumo \& Pitlo, Bab-Bab Penemuan Hukum, Citra Aditya Bakti, Bandung, 1993. hal 42-43.
} 
mengambil putusan. Disisi lain, kehadiran bahan hukum yang begitu masif telah mengundang keinginan intelektual untuk mempelajari, seperti menggolongnggolongkan, mensistematisir, mencari perbedaan dan persamaan, menemukan asas dibelakangnya dan sebagainya. Dalam konteks tersebut suatu teorisasi mengenai adanya tatanan hukum yang kukuh dan rasional merupakan obsesi dari positivisme $^{45}$.

John Austin, seorang positivisme utama, mempertahankan bahwa satusatunya sumber hukum adalah kekuasan tertinggi dalam suatu Negara. Austin mengartikan ilmu hukum (jurisprudence) sebagai teori hukum positif yang otonom dan dapat mencukupi dirinya sendiri. Ilmu tentang hukum berurusan dengan hukum positif dengan hukum lain yang diterima tanpa memperhatikan kebaikan dan kejelekan. Tugas ilmu hukum hanyalah menganalisis unsure-unsur secara nyata ada dari sitem hukum moderen. Sekalipun diakui bahwa ada unsurunsur yang bersifat historis, tetapi diabaikan dari perhatian. Hukum adalah perintah dari kekuasaan politik yang berdaulat dalam suatu negara ${ }^{46}$.

Sumbangan Austin yang paling penting dalam teori hukum adalah digantinya perintah yang berdaulat yakni Negara bagi tiap-tiap cita keadilan dalam definisi hukum, Austin mendefinisikan hukum sebagai ${ }^{47}$ : Peraturan yang diadakan untuk memberi bimbingan kepada makhluk yang berakal oleh mahkluk yang berakal yang berkuasa diatasnya (A rulle laid down for guidance of an intellegent being by an intellegent being having power over him).

Hukum sepenuhnya dipisahkan dari keadilan dan didasarkan tidak atas gagasan-gagasan tentang yang baik dan buruk, yang didasarkan atas kekuasaan yang lebih tingi. Menurut Austin, hukum dibagi dalam ${ }^{48}$ :

1) Hukum yang diadakan oleh Tuhan untuk manusia (Hukum Tuhan), dan

2) Undang-undang yang diadakan oleh manusia untuk manusia (hukum manusia). Hukum manusia dapat dibagi ke dalam:

\footnotetext{
45 Khudzaifah Dimyati., Teorisasi Hukum, Studi Tentang Perkembangan Pemikirian Hukum Di Indonesia 1945-1990. Muhamadiyah University Press, Surakarta, 2005. hal 61-62.

${ }^{46}$ Satjipto Rahardjo, Op Cit, Hal 268.

${ }^{47}$ W. Friedman. Op cit, hal 149.

${ }^{48}$ W.Friedman. Opcit, hal 150.
} 
a. undang-undang yang disebut hukum yang sebenarnya (positif law), yaitu Undang-undang yang diadakan oleh kekuasaan politik untuk orang-orang politis yang merupakan bawahannya, dan

b. Undang-undang yang disebut hukum yang tidak sebenarnya adalah undang-undang yang tidak diadakan langsung atau tidak langsung oleh kekuasaan politik (morality positif).

Positivisme yang lain adalah teori murni hukum Kelsen (the pure of law theory). Hans Kelsen tegas tidak menganut hukum alam walau mengemukakan adanya azas-azas hukum umum sebagaimana tercermin dalam Grundnorm/ Ursprungnormnya. Ada dua teori yang dikemukan Hans Kelsen ${ }^{49}$;

1) Pertama ajaran tentang hukum murni yang menyatakan bahwa hukum itu harus dibersihkan daripada anasir-anasir yang tidak yuridis seperti etis, sosiologis, politis, dan sebagainya, dan;

2) Kedua, tentang Stufenbau des recht yang mengutamakan tentang hierarkis dari pada peraturan perundang-undangan.

Fokus utama teori hukum murni bukanlah salinan ide transendental yang sedikit banyak tidak sempurna ${ }^{50}$, teori hukum murni ini tidak berusaha memandang hukum sebagai anak cucu keadilan, sebagai anak dari orang tua yang suci. Ia memegang teguh suatu perbedaan yang tegas antara hukum empirik dan keadilan transendental dengan meniadakan keadilan transendental dari perhatian spesifik.

Ajaran hukum murni Kelsen tidak memberi tempat unsur sosiologis, ia hanya memandang hukum sebagai sollenskategori dan bukan seinskategori ${ }^{51}$; orang mentaati hukum karena merasa wajib mentaatinya sebagai suatu kehendak negara. Hukum itu tidak lain merupakan kaidah ketertiban yang menghendaki orang mentaatinya sebagaimana seharusnya. Seorang pembeli seharusnya membayar, namun apakah dalam kenyataannya si pembeli membayar atau tidak, itu soal yang menyangkut kenyataan dalam mesyarakat dan hal itu bukan menjadi wewenang ilmu hukum.

\footnotetext{
${ }^{49}$ Lili Rasyidi., Dasar-dasar Filsafat Hukum., Citra Aditya Bakti, Bandung, 1996. hal 63.

${ }^{50}$ Kudzaifah Dimyati, Op cit, hal 67.

${ }^{51}$ Lili Rasyidi, Op cit. hal 64.
} 
Ajaran Stufenbautheory berpendapat bahwa suatu sistem hukum adalah merupakan suatu hierarkhis dari pada hukum dimana suatu ketentuan hukum tertentu bersumber pada ketentuan hukum lainnya yang lebih tinggi ${ }^{52}$. Sebagai ketentuan tertinggi adalah Grundnorm atau norma dasar yang bersifat hipotetis. Ketentuan lebih rendah adalah lebih konkrit dari ketentuan yang lebih tinggi.

Dalam sistem hukum Indonesia dikenal tata urutan peraturan perundangundangan sebagaimana diatur dalam Undang-Undang Republik Indonesia Nomor 12 Tahun 2011 Tentang Pembentukan Peraturan Perundang-Undangan. Menurut Pasal 7 UU 12 tahun 2011, Jenis dan hierarki Peraturan Perundang-undangan terdiri atas:

1) Undang-Undang Dasar Negara Republik Indonesia Tahun 1945;

2) Ketetapan Majelis Permusyawaratan Rakyat;

3) Undang-Undang/Peraturan Pemerintah Pengganti Undang-Undang;

4) Peraturan Pemerintah;

5) Peraturan Presiden;

6) Peraturan Daerah Provinsi; dan

7) Peraturan Daerah Kabupaten/Kota.

Eksponen lain positivisme hukum ini adalah Lon Foller, yang menekankan pada isi hukum positif. Menurut teori Lon Foller ${ }^{53}$, hukum positif harus memenuhi delapan persyaratan moral, yaitu:

1) Harus ada aturan sebagai pedoman dalam pembuatan keputusan. Perlunya sifat tentang persyaratan sifat keumuman;

2) Aturan-aturuan yang menjadi pedoman bagi otoritas tidak boleh dirahasiakan melainkan harus diumumkan.;

3) aturan harus dibuat untuk menjadi pedoman dikemudian hari, artinya hukum tidak boleh berlaku surut;

4) hukum harus dibuat sedemikian ruoa sehingga dapat dimengerti oleh rakyat;

5) Aturan tidak boleh bertentangan satu sama lain;

\footnotetext{
${ }^{52}$ Lili Rasyidi, Opcit, hal 65.

${ }^{53}$ Kudzaifah Dimyati, Opcit. Hal 63.
} 
6) Aturan tidak boleh mensyaratkan peilaku yang diluar kemampuan pihakpihak yang terkena, artinya tidak memerintahkan sesuatu yang tidak mungkin dilakukan;

7) dalam hukum harus ada ketegasan, hukum tidak boleh diubah sewaktu-waktu;

8) Harus ada konsistensi antara aturan-aturan s ebagaimana yang diumumkan dengan pelaksanaan kenyataan.

Pada lain pihak, terdapat dua bentuk positivisme hukum ${ }^{54}$, yaitu positivisme yuridis dan positivisme sosiologis ${ }^{55}$. Dalam positivisme yuridis hukum dipandang sebagai suatu gejala tersendiri, yang perlu diolah secara ilmiah. Tujuan positivisme yuridis ini adalah pembentukan struktur-struktur rasional sistemsistem yuridis yang berlaku. Sebab hukum dipandang sebagai hasil pengolahan ilmiah belaka, akibatnya pembentukan hukum menjadi profesional. Hukum modern adalah ciptaan para ahli dibidang hukum. Dalam positivisme sosiologis hukum dipandang sebagai bagian kehidupan masyarakat.

Prinsip-prinsip positivisme hukum dapat diringkas sebagai berikut ${ }^{56}$ :

1) Hukum adalah sama dengan undang. Dasarnya adalah bahwa hukum muncul sebagai berkaitan dengan negara; hukum yang benar adalah hukum yang erkaitan dalam suatu negara.

2) Tidak terdapat suatu hubungan mutlak antara hukum dan moral. Hukum itu tidak lain dari hasil karya para ahli di bidang hukum.

3) Dalam positivisme yuridis ditambah bahwa hukum adalah closed logical system. Peraturan-peraturan dapat diduksikan dari undang-undang yang berlaku tanpa meminta bimbingan dari norma-norma sosial, politik, dan moral. Dalam Positivisme sosiologis hukum ditanggapai sebagai terbuka bagi kehidupan masyarakat, yang harus diselidiki melalui metode-metode ilmiah.

\footnotetext{
${ }^{54}$ Menurut Dosen Hari Puradi, sebagaimana yang disampaikan dalam kuliah Teori Hukum pada tanggal 27 September 2013, Positivisme hukum (legal positivism) terdiri dari positivisme keras yakni yang memisahkan hukum dan moral, dan positivisme lunak yaitu memandang bahwa moral berinteraksi dengan hukum.

${ }_{55}^{55}$ Theo Huijbers., Op cit. hal 33.

${ }^{56}$ Theo Huijbers, Op cit. hal 33.
} 
Belum ada teori atau ilmu pengetahuan yang berhasil mengklaim dirinya sebagai kebenaran abadi karena tidak bisa dibuktikan dengan kesalahannya. Menurut Karl Popper ${ }^{57}$, ilmu pengetahuan berkembang secara evolusioner dari problem situasi (PS1) yang selanjutnya dibuat pernyataan yang belum didukung bukti (konjektur) yang dirangkum menjadi tentatif theory (TT) atau teori sementara yang dijelaskan dengan konklusi eksplanatif dan prediktif, dan diuji dengan falsifikasi atau error elimination (EE1), hinggá teori itu salah dan jika berhasil maka tentatif teori (TT) tumbang, dan jika gagal maka lahir teori baru (PS2). Perkembangan ilmu pengetahuan versi Karl Popper dapat digambarkan dalam skema sebagai berikut: $\mathrm{PS} 1 \rightarrow \mathrm{TT} \rightarrow \mathrm{EE} 1 \rightarrow \mathrm{PS} 2$

Berdaasarkan pandangan Karl Popper tersebut, dalam teori hukum selalu tumbuh dan berkembang dengan munculnya teori-teori baru, tanpa meninggalkan teori lama. Teori Hukum muncul dari abad ke abad dan dari generasi ke genarasi, tidak hanya memperlihatkan warna kosmologi dan semangat zamanya , tetapi juga memunculkan pergeseran cara pandang sesuai peralihan zaman ${ }^{58}$.

Teori positivism hukum yang lahir di abad ke -19 , tentu mendapat kritikan dari berbagai teori hukum yang berkembang baik pada abad-abad sebelumnya maupun pada abad berikutnya, seperti: Natural of law theory, Sociological jurisprudence, Critical legal studies, Pragmatic legal realism, hinggá pada teori hukum progresif. Pada tulisan ini, teori positivisme hukum akan dikritisi melalui beberapap teori post-modern.

\section{Kritik Terhadap Teori Positivisme Hukum}

Hampir semua ahli hukum yang memberikan pemahaman tentang hukum yang berlainan. Sebab, hukum banyak seginya dan demikian luasnya, sehingga tidak mungkin orang menyatukannya dalam satu rumus secara memuaskan. Positivisme hukum yang pada pokoknya memandang hukum adalah undangundang, tidak ada hubungan antara hukum dan moral, hukum terlepas dari anasiranasir non hukum, mendapat kritik dari berbagai pandangan.

Kritik terhadap teori positivisme tersebut antara lain, bahwa:

\footnotetext{
${ }^{57}$ Sebagaimana disampaikan oleh Like Wilardjo, dalam Kuliah Filsafat Ilmu pada program S3 Ilmu Hukum UNS, tanggal 21 September 2013.

${ }^{58}$ Bernad L. Tany. Dkk., Opcit. Hal 15.
} 
1) Doktrin kepastian hukum sebagai anak ajaran legisme yang dibela oleh para pengikut teori hukum murni ini, yang mengagungkan rasionalisme dalam kajian hukum dan praktik peradilan adalah sesungguhnya ajaran yang berkembang dan didukung para penganut pada suatu era tatkala proses demokratisasi tengah berlangsung, dengan cita-cita bahwa kekuasaan negara harus bisa dibatasi dan dikontrol oleh hukum. Negara haruslah dikonstruksi sebagai „negara hukum’ dan bukan „negara kekuasaan, ${ }^{59}$.

Infrastruktur negara hukum tak pelak lagi adalah masyarakat warga (civil society), dan bukan masyarakat yang mengenal dikotomi kawula-Gusti. Di tengah kehidupan masyarakat, setiap manusia harus diakui berkedudukan sama di hadapan hukum dan hakim ${ }^{60}$.

2) Dalam kenyataan, apa yang dicita-citakan bahwa "setiap warga negara berkedudukan sama di hadapan hukum dan kekuasaan" itu tidak selamanya dapat direalisasi. Apa yang telah diberikan di dalam cita-cita dan konsep normatif tidak selalu merupakan diskripsi apa yang dapat ditemui dalam pengalaman yang nyata. Menurut konsep hukumnya setiap warga masyarakat dan warga negara itu dianggap berkedudukan sama, namun dalam realitas kehidupan yang sudah bersifat serba kontraktual ini kesepakatankesepakatan yang terjadi antar-pihak tidaklah selalu dan selamanya mencerminkan perlindungan kepentingan yang berimbang ${ }^{61}$.

3) Menempatkan para penegak hukum untuk berfikir dan bertidak secara legal formalistic, dengan menempatkan keadilan hukum (legal justice) sebagai tujuan hukum. Dalam perkara-perkara tertentu, positivisme hukum tidak dapat memberikan solusi. Sesuai dengan Pasal 28 UU No. 4 tahun 2004 maka hakim akan menemukan hukum yang hidup dan berkembang dalam masyarakat, bukan dalam UU (hukum positif). Sebagai contoh Perkara

\footnotetext{
${ }^{59}$ Sotandyo Wignjosobroto, Terwujudnya Peradilan Yang Independen Dengan Hakim Profesional Yang Tidak Memihak Sebuah risalah ringkas, dimaksudkan untuk rujukan ceramah dan diskusi tentang "Kriteria dan Pengertian Hakim Dalam Perspektif Filosofis, Sosiologis dan Yuridis" yang diselenggarakan dalam rangka Seminar Nasional bertema "Problem Pengawasan Penegakan Hukum di Indonesia" diselenggarakan oleh Komisi Yudisial dan PBNU-LPBHNU di Jakarta 8 September 2006. hal 2.

${ }^{60}$ Ibid. hal 3

${ }^{61}$ Ibid., hal 3
} 
Pengangkatan Anak sebelum berlakunya UU tentang perlindungan anak, masih tunduk kepada dan berlaku hukum adat ${ }^{62}$.

Ketentuan Pasal 28 UU Pokok Kekuasan Kehakiman dan Yurisprudensi tersebut lebih condong menganut pada Madzab sejarah sebagai dan yang menjadi solusinya. Sebagaimana dalam bukunya Vonsavigny $^{63}$ yang termashur Von Beruf Unserer Zeit fur Gesetgebuung und Rechtswissenschafttentang tugas bagi pembentuk undang-undang dan ilmu hkum, antara lain dikatakan: Das Recht wird nicht gemacht, est ist und wird mit dem volkeHukum itu tidak dibuat akan tetapi tumbuh dan berkembang bersama masyarakat. Pangkal tolaknya bahwa di dunia ini terdapat bermacam-mcam bangsa yang paa tiap bangsa mempunyai volkgeist-jiwa rakyat yang berbedabeda baik menurut waktu maupun tempat. Pencerminan adanya jiwa ini nampak pada kebudayaan dan termasuk hukum. Hukum Sangat tergantung pada jiwa rakyat dan yang menjadi isi dari pada hukum itu ditentukan oleh pergaulan hidup manusia dari masa ke masa. Hukum berkembang dari suatu masyarakat yang sederhana yang pencerminannya nampak dalam tingkah laku semua individu kepada masyarakat yang modern dan kompleks.

4) Menempatkan hakim sebagai corong undang-undang; yang tidak dapat berekspresi untuk membuat putusan yang memenuhi rasa keadilan sosial (social justice) maupun keadilan substantif (substantive justice); Pada era Reformasi ini, belum dapat dikatakan bahwa putusan-putusan hakim berkontribusi besar bagi perubahan masyarakat Indonesia ${ }^{64}$.

Disinilah hukum modern berada di persimpangan ${ }^{65}$, sebab antara keadilan sudah diputuskan dan hukum sudah diterapkan terdapat perbedaan yang Sangat besar. Wilayah keadilan tidak peprsi sama dengan wilayah hukum

\footnotetext{
${ }^{62}$ Yurisprudensi MA No.382 K/Pdt/1985 di mana MA berpendapat bahwa seseorang yang sejak kecil telah dipelihara, kemudian dikithankan bahkan setelah dewasa juga dikawinkan oleh kedua orang tua yang memelihara, dari fakta tersebut dapat disimpulkan bahwa seseorang adalah anak angkat dari kedua orang yang memeliharanya.

${ }^{63}$ Sebagaimana dikutip dalam: Lili Rasyidi. Op Cit. hal 69.

${ }^{64}$ Widodo Dwi Putro., Kritik Terhadap Paradigma Positivisme Hukum, Genta Publishing, 2011, hal 1.

${ }^{65}$ Satjipto Rahardjo., dalam Otje Salman, dkk. Op Cit. hal 147.
} 
positif. Keadaan gawat tersebut tampil dengan menyolok pada waktu kita berbicara tentang supremasi hukum. Apakah yang kita maksud? Supremasi keadilan atau supremasi undang-undang? keadaan persimpangan tersebut juga memunculkan pengertian-pengertian seperti ,formal justice" atau "legal Justice" di satu pihak dan "substancial justice " di pihak lain.

Putusan hukum yang dikehendaki masyarakat adalah putusan-putusan hakim yang lebih responsif sebagaimana yang dianut dalam teori hukum responsif yang dikembangakan oleh Nonet \& Selnick, yang dipolulerkan oleh Satjipto Rahardjo ${ }^{66}$.

Teori-teori Roscou Pound mengenai kepentingan-kepentingan sosial ${ }^{67}$, merupakan sebuah usaha yang lebih eksplisit untuk menegembangkan statu model hukum responsif. Dalam perspektifi ini ${ }^{68}$, hukum yang baik seharusnya menawarkan sesuatu yang lebih baik dari pada keadilan formal prosedural.

5) Hukum merupakan ilmu interdisipliner, sehingga tidak dapat hukum hanya dilihat dari satu segi saja yakni Uadng-undang. Hukum berada ditengahtengah masyarakat, maka tidak akan lepas dari kehidupan manusia dala masyarakat. Hukum yang baik adalah hukum yang sesuai dengan hukum yang hidup dan berkembang di dalam masyarkat, sebagaimana teori yang berkembang di Amerika, yang dipelopori oleh Roscou Pond, Eugin Ehrlich, Benjamin Cadozo, dll, yang disebut dengan sociological jurisprudence.

Sociological Jurisprudence ${ }^{69}$ merupakan suatu teori hukum yang mempelajari pengaruh timbal balik antara hukum dan masyarakat dan sebaliknya. Pendekatannya bermula dari hukum ke masyarakat, dan mengetengahkan pentingnya Living Law-hukum yang hidup di dalam masyarakat. Sociological Jurisprudence berpegang kepada pendapat pentingnya akal dan pengalaman.

\footnotetext{
${ }^{66}$ Achmad Ali., Op cit. hal 478-479.

67 Teori Kepentingan sosial meliputi enam jenis kepentingan;1) dalam soal keamanan umum, 2) menyangkut keamanan institusi sosial, 3) menyangkut moral umum, 4) menyangkut pengamanan sumber daya sosial, 5) menyangkut kemajuan sosial, dan 6) menyangkut kehidupan individu. Baca Bernad L. Tanya., dkk. Hal 141-142.

${ }^{68}$ Philippe Nonet \& Philip Selznick., op cit. hal 83-84

${ }^{69}$ Lily Rasyidi., Op cit. hal 70.
} 
Menurut Soetandyo Wingjosoebroto ${ }^{70}$, istilah sociological mengacu pada pemikiran realisme dalam imu hukum (Holmes), yang meyakini bahwa meskipun hukum adalah sesuatu yang dihasilkan melalui proses yang dapat dipertanggungjawabkan secara logika imperative, namun the laife of law has not been logic, it is (socio-psychological) experience. Hakim yang bekerja haruslah proaktf membuat putusan untukmenyelsaikan perkara dengan memperhatikan kenyataan-kenyataan sosial, dengan demikian putusan hakim selalu memenuhi rasa keadilan masyarakat. Dan dari pemikiran inilah lahir doktrin baru dalam Sociological Jurisprudence tentang Law is a tool of social enginering ${ }^{71}$.

Hukum lahir dari opinio necessitatis warga masyarakat. Hukum timbul secara langsung dari kebutuhan rutin masyarakat dalam kehidupan sosial mereka Inilah yang oleh Eugen Ehrlich disebut living law. Ehrlich menyebut "hukum yang hidup" dengan istilah Rechtsnormen, berbeda denagn Entscheidungsnormen dan Rechtssatze. Rechtssatze adalah peraturanperaturan hukum yang telah dirumuskan dalam bentuk peraturan perundangan. Entscheidungsnormen merupakan norma-norma keputusan yang merupakan pedoman bagi pengadilan ${ }^{72}$.

Karena merupakan aturan yang ditambahkan 'dari luar', maka Entscheidungsnormen dan Rechtssatze tidak tergolong 'hukum yang hidup'. Tapi jika Entscheidungsnormen dan Rechtssatze telah menjadi bagian internal dari kehidupan masyarakat, maka ia akan beralih status sebagai 'hukum yang hidup' juga. Jadi, Entscheidungsnormen dan Rechtssatze dapat menjadi Rechtsnormen mana kala telah berfungsi sebagai norma yang hidup dalam kehidupan nyata masyarakat ${ }^{73}$.

6) Dalam Tradisi hukum civil law, peran pemerintah dan parlemen dominan dalam pembentukan hukum berupa peraturan perundangan tertulis; dan

\footnotetext{
${ }^{70}$ Sebagaimana yang dikutip oleh Sulistyowati Irianto, dkk dalam: Kajian Socio-legal, khususnya dalam "Memperkenalkan Kajian Socio-legal dan Implikasi metodologisnya.". Pustaka Larasan, Denpasar, Universitas Indonesia, Jakarta., Univesitas Leiden, 2012. hal 4.

${ }^{71}$ Ibid., hal 4.

72 Bernad L. Tanya, dkk. Op cit hal 128-129.

${ }^{73}$ Bernad L. Tanya, dkk. Op cit. Hal 129.
} 
positivisme hukum memberi pemahaman pada hakim bahwa hukum sematamata hanya berurusan dengan norma-norma ${ }^{74}$. Maka, di sini kerja hukum dan hakim, yang menurut doktrinnya disyaratkan dan diisyaratkan netral dan tak boleh memihak itu, dalam kenyataannya sering berefek membiarkan (bertolak dari dalih "harus netral") terjadinya berbagai kesenjangan yang memperlihatkan betapa yang satu memperoleh lebih, sedangkan yang lain, yang umumnya jumlahnya justru massal, memperoleh kurang. Tengok saja misalnya apa yang pernah terjadi di negeri ini selama ini $^{75}$, tatkala undangundang perburuhan dibuat oleh anggota-anggota DPR yang amat didominasi oleh suara-suara konglomerat, dan/atau oleh para pejabat eksekutif ataupun legislative yang membuka diri pada lobi-lobi para investor, namun acapkali menutup diri dari tuntutan-tuntutan para buruh miskin.

Dilihat dari optik Pancasila, maka jelas bahwa bagi bangsa Indonnesia hukum hukum berfungsi sebagai alat yang akan mengantarkan bangsa Indonesia menuju masyarakat yang adil dan makmur berdasarkan Pancasila. Disamping itu, adanya fakta bahwa bangsa Indonesai adalah bangsa yang pluralis yang Berbenika Tunggal Ika namun dalam Persatuan, terdapat fakta adanya hukum plural $^{76}$.

Karakter hukum yang sebenarnya dibutuhkan bangsa Indonesai sebagai alat untuk mencapai tujuan nasionalnya adalah hukum yang dapat mengakomodir sifat kemajemukan bangsa yang tersebar dari sabang sampai Merauke dengan berbagai suku bangsa dengan otoritas-otoritas lokal tradisonal yang otonom. Hal utama yang harus dilakukan dalam pembangunan hukum adalah melakukan harmonisasi hukum, bukan melakukan unifikasi dan koodifikasi ${ }^{77}$. Berdasarkan teori Sociological jurisprudence, dengan adanya pluralisme hukum, maka pembentukan hukum harus berdasarkan pada nilai-nila yang tumbuh dan berkembang dalam satuan-satuan masyarakat yang pluralis

\footnotetext{
${ }^{74}$ Ibid. hal 7.

${ }^{75}$ Soetandyo Wignjosoebroto., Op Cit. hal 4.

${ }^{76}$ Firman Muntaqo., Opcit. Hal 187.

${ }^{77}$ Firman Muntaqo., Opcit. Hal 187.
} 
tersebut, dan berdasar Teori Instrumental ${ }^{78}$, yang secara nyata hukum digunakan dan dimanfaatkan masyarakat dalam kehidupan berhukum (hukum yang fungsional) dan bukan hukum yang diciptakan berdasarkan nilai-nila yang secara a priori (bersifat abstrak) ditetapkan dan dianut oleh para ahli hukum yang berfaham positivistis dan normatif.

\section{Penutup}

Berdasarkan uraian-uraian sebagaimana tersebut di atas, maka dapat diambil suatu kesimpulan yang pada dasarnya bahwa Positivisme hukum:

1. Pembentukan hukum didasarkan pada nilai-nilai yang abstrak, bukan nilainilai yang hidup dan berkembang dalam masyarakat, sehingga hukumnya lebih represif, dan bukan responsive. Hukum tidak fungsional dan tidak pragmatis, Ia hanya melindungi sekelompok warga masyarakat elit, sehingga equality before the law dan rule of law, tidak jalan.

2. Memprioritaskan doktrin kepastian hukum dibandingkan dengan keadilan dan kemanfaatan. Putusan hakim menempatkan keadilan legal formal (Legal justice) prosedural dibandingkan keadilan substantive dan keadilan sosial (social justice).

Berasarkan kesimpulan tersebut di atas, maka dapat disampaikan saransaran sebagai berikut:

1. Dalam pembentukan hukum harus mendasarkan pada nilai-nilai yang hidup dan berkembang dalam satuan -satuan masyarakat yang sesuai dengan nilainilai yang terkandung dalam dasar falsafah bangsa yaitu Pancasila. Sehingga dapat tercipta hukum responsive maupun hukum progresif.

2. Doktrin kepastian hukum perlu diubah ke dalam doktrin keadilan dan kemanfaatan, sehingga keadilan substantive dan keadilan sosial dapat tercapai. Hakim harus kreatif tidak terbelenggu dengan rumusan norma dalam

\footnotetext{
${ }^{78}$ Hukum itu dibentuk, bagaimana hukum itu untuk mencapai tujuan tertentu. Pragmatism:: moment filsafat, yang menyatakan bahwa sebuah ideologi /proposisi itu benar jika ia bekerja secara memuaskan. Artinya proposisi itu benar jika di dalam praktek memiliki konsekuensi diterima secara praktis. Ajaran-ajaran Hukum pragmatis: mana hukum yang fungsional, maka itu yang praktis.
} 
undang-undang, dengan mendasarkan pada nilai-nilai yang hidup dan berkembang dalam masyarakat. 


\section{Daftar Pustaka}

Ali, Achmad, Menguak Teori Hukum (Legal Theory) dan Teori Peradilan (Judicialprudence), Jakarta: Kencana Prenada Group, 2009.

Backer.Larry Cata', Harmonizing Law In An era Of Globalization, Convergance,

Divergance, and Resistenace., North Carolina: Carolinena Academic Pres, Durham, 2007.

Dimyati, Khudzaifah, Teorisasi Hukum, Studi Tentang Perkembangan Pemikiran Hukum Di Indonesia 1945-1990. Surakarta: Muhamadiyah University Press, 2005.

David, Rene' and John E.C. Brierley., Major Legal System in the Word Today., London: Stevens \& Sons, 1978.

Friedman., W, Teori dan Filsafat Hukum, Telaah Kritis atasTeori-teori Hukum (susunan I), diterjemahkan dari buku aslinya "Legal Theory" oleh Mohamad Arifin., Jakarta : Rajawali, 1990.

Harris. J.W., Legal Philosophies, London: Butterworths, 1980.

Huijbers, Theo, Filsafat Hukum, Yogyakarta: Kanisius, 1991.

Irianto, Sulistyowati, dkk. dalam: Kajian Socio-legal, dalam "Memperkenalkan Kajian Socio-legal dan Implikasi metodologisnya.”. Pustaka Larasan, Denpasar, Universitas Indonesia, Jakarta: Univesitas Leiden, 2012

Mertokusumo, Sudikno \& Pitlo, Bab-Bab Penemuan Hukum, Bandung : Citra Aditya Bakti, 1993. , Hukum Acara Perdata, Yogyakarta: Liberty, 1993.

Muntaqo, Firman. Meretas Jalan Bagi Pembangunan Tipe Hukum Prograsif Melalui Pemahaman Terhadap Peranan Mazhab Hukum Positivis dan Non Positivis dalam Kehidupan Berhukum Indonesia. Dalam Buku "Satjipto Rahardjo" berjudul Membedah Hukum Progresif, Jakarta: Kompas, 2008.

Nonet, Philippe dan Philip Selznick ., Hukum Responsif, Terjemahan dari Raisul Mutaqien, Bandung: Nusa Media, 2010. 
Peursen, C.A. Van, Strategi Kebudayaan, diterjemahkan oleh Dick Hartono., Kanisius, Yogyakarta., 1988.

Patterson, Jefferson White Dennis., Introduction To The Philosophy Of Law, Reading And Case, London: Oxford University Press, 1999.

Putro, Widodo Dwi, Kritik Terhadap Paradigma Positivisme Hukum, Yogyakarta: Genta Publishing, 2011.

Rasyidi.Lili, Dasar-dasar Filsafat Hukum. Bandung: Citra Aditya Bakti, 1996.

Sidharta, Bernard Arief, Refleksi Tentang Struktur Ilmu Hukum, Bandung: Penerbit Mandar Maju, 2009.

Rahardjo, Satjipto, Ilmu Hukum, Bandung: Citra Aditya Bakti, 1991.

Salman. S. Otje dan Antón F. Susanto., Teori Hukum, Mengingat, Mengumpulkan dan Membuka Kembali., Refika Aditama, Bandung, 2004., hal 21

Suriasumantri, Jujun S, Filsafat Ilmu Sebuah Pengantar Populer, Jakarta: Pustaka Sinar Harapan, 2009.

Tanya, Bernard L. dkk., Teori Hukum, Strategi Tertib Manusia Lintas Ruang dan Generasi., Gentha Publishing, 2013.

Tamanaha, Brian Z. Realistic Socio-Legal Theory, New York: Oxford University Pres, 2004.

, Law as A Means To An End,New York : Cambridge University Pres, 2006.

Wignjosoebroto, Soetandyo, "Logika Filsafat Positivisme Dalam Pembangunan Epistemologi Hukum” dalam rangka „Kongres Ilmu Hukum’ diselenggarakan di Universitas Diponegoro 9-20 Oktober 2012.

-----------------,Terwujudnya Peradilan Yang Independen Dengan Hakim Profesional Yang Tidak Memihak Sebuah risalah ringkas, dimaksudkan untuk rujukan ceramah dan diskusi tentang "Kriteria dan Pengertian Hakim Dalam Perspektif Filosofis, Sosiologis dan Yuridis" yang diselenggarakan dalam rangka Seminar Nasional bertema "Problem Pengawasan Penegakan Hukum di Indonesia" diselenggarakan oleh Komisi Yudisial dan PBNU-LPBHNU di Jakarta : 8 September 2006. 
, Dari Hukum Kolonial Ke Hukum Nasional, Dinamaika Sosial Politik Dalam Perkembangan Hukum di Indonesia, Jakarta: Raja Grafika, 1994.

\section{Sumber lain :}

Kitab Undang-undang Hukum Perdata

Kitab Undang-undang Hukum Dagang

Kitab Undang-undnag Hukum Pidana

Undang-undang Nomor 12 Tahun 2011 Tentang Pembentukan Peraturan Perundang-Undangan

Yurisprudensi MA No.382 K/Pdt/1985 di mana MA berpendapat bahwa seseorang yang sejak kecil telah dipelihara, kemudian dikithankan bahkan setelah dewasa juga dikawinkan oleh kedua orang tua yang memelihara, dari fakta tersebut dapat disimpulkan bahwa seseorang adalah anak angkat dari kedua orang yang memeliharanya. 